\title{
COLONEL HENRY DODGE AND HIS REGIMENT OF DRAGOONS ON THE PLAINS IN 1834
}

The Annals throughout its existence has presented original and published records of the earlier phases of the society which forms our state. We cannot if we would avoid or escape notice of the lives and services of men who contributed largely to the foundations. At the transition from aboriginal to the organized state, is conspicuously found the career of General Henry Dodge. He was first and last a military figure. His name is found among the great names of the old army who not only figured in wars, but in explorations. Their reports were bases of procedure by the federal government. 'They often passed out of the army into organized activity as executives. One who studies that period encounters the names of Meriwether Lewis, William Clark, Zebulon M. Pike, and John C. Fremont.

The Annals belicves it is a public service to print Dodge's writings, even when, in whole or in part, they may have been published elsewhere.

There is a special reason for this. In the long future the student of western sources will be confused with the name Dodge. 'Toward the afternoon of Henry Dodge's life in the then Indian country, came Richard Irving Dodge, ${ }^{1}$ whose writings of Indian life are many times referred to as "Dodge's." In the afternoon of R. I. Dodge's life, in the same region, came Grenville M. Dodge, whose writings and reports many times bear upon similar subjects in the same areas and times. There was no near kinship among them.

Upon the specific point that an Indian had been seen to drive an arrow completely through the body of a buffalo, Grenville M. Dodge told us that R. I. Dodge's statement had been attributed to himself; that he had witnessed a like performance, but had not stated the fact in print until after its publication.

The subjoined account of Henry Dodge's explorations and

1Richard Irving Dodge was a native of North Carolina. He hecame a cadet at West Point Military Academy in 184.4. was breveted second licutenant in 1848, became first lieutenant in 1855 , captain in 1861 , lieutenant colonel in is63 served in different regiments of the Regular Army from the end of the Civil War until he was made a colonel and aide-de-camp to General Sherman January 1, 1881, and server in that position until June 26,1882 , when he became colonel of the Eleventh Infantry, and retired May 19, 1891. He died June 10, 1895. 
services on the southwestern. plains is a notable incident in a life of an individual who was chief executive of Wisconsin Territory throughout the period when Iowa was part of that territorial jurisdiction. As a contribution upon the early west, the Annals regards it eminently appropriate.-Editor.

\section{JOURNAL OF THE CAMPAIGN}

Fort Gibson, August 26, 1834 .

To Col. Henry Dodge,

U. S. Dragoons.

Colonel:

In obedience to your instructions I have made a journal of the campaign of the regiment of Dragoons for the summer of 1834 .

With great respect, Yr. obt. Serv't,

'T. W. WHEELOCK, 1st Lieut. Dragoons.

In consequence of the late arrival of the companies from Jefferson Barracks the regiment did not move as early as could have been wished.

The nine companies destined for the campaign, (Capt.' Wharton's Company [A] marched in May to escort a body of traders to Santa $\mathrm{Fe}$ ) began the movement from Camp Jackson on the 15th of June, and under the direction of the field and company officers encamped on the west bank of the Arkansas three miles from Fort Gibson; thence moved eighteen miles westward to Camp Rendewyous-strength of the regiment, about five hundred.

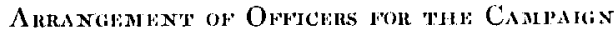

Colonel, Henry Dodge

Lt. Colonel, S. W. Kearney

Major, R. B. Mason

\section{Staff}

Adjutant, 1st Lt. I. W. Hamilton

Ordnance Officer \&c., 1st Lt. T. B. Wheelock

Act'g Asst. Qr. Master, 1st Lt. Thos. Swords

Actg. Asst. Com. Subsistence, 2nd Lt. John S. Van Derveer Company Officers

Company B, Capt. Sumner, 2nd Lt. Burgoin, Brevet 2nd Lt. McClure

Company C, Capt. Duncan, Brevet 2nd Lt. Bowman

Company D, Capt. Hunter, 1st Lieut. Moore, 2nd Lt. Steen

Company E, Capt. Perkins, Brevet 2nd Lt. Kingsbury

Company F, 1st Lt. Davis, Brevet 2nd Lt. Eastman, 2nd Inft.

Company G, 1st Lt. Cooke, 2nd Lt. Terrett

Company H, Capt. Boone, Brevet 2nd Lt. Ury

Company I, Capt. Brown, Brevet 2nd Lt. Edwards

Company $\mathrm{H}$, 1st Lt. Izard, 2nd Lt. Shambaugh 
Eight companies (Company $\mathbf{K}$ left at Camp Jackson to complete preparations for the march) were assembled at Camp Rendezvous on the evening of the 20 th of June.

June 21. 'Twenty-three men pronounced by the surgeon unfit for the campaign, sent back to Fort Gibson. The regiment took up the line of march for the Washita, upon the new road made by Gen. Leavenworth, at 8 o'clock in the morning, moved twenty miles southwest; crossed the North Fork of the Canadian and encamped one mile thence; difficulty with wagons ascending the bank of this stream, assistance of thirty or forty men required to each. Good water at our camp-great want of it on the road. Sound of the rapids of the North Fork cheering to men and horses. With the command seventy beeves. Face of the country, today in general, open rolling prairie. Soil light; a few miles from our halt much timber and stony land.

Agreeably to previous arrangement four bands of Indians joined us today, viz: Eleven Osages, eight Cherokees, six Delawares and seven Senecas. These men are to serve as guides, hunters and interpreters, also as representatives of their several nations, should we, as we hope to do, meet with the Pawnees, and thus open the way to a friendly understanding between these nations. Among these Indians are some of the elite of the nations to which they belong.

Dutch, chief of the Cherokee party, remarkable for personal beauty, daring character, and successful enterprises against the Osages; George Buttet, or Pondaguesa, is the principal man of the Delaware party, and distinguished for his warlike qualities; Beatto, a Frenchman, who has lived nearly all his life among the Osages, has charge of this band, and is celebrated for his skill as a hunter; and Denathdeago is the leader of the seven Senecas. We take with us under conduct of the Osages, two Indian girls, one a Kiowa, about fifteen years, captured by the Osages a year or two since. The other a Pawnee prisoner eighteen years of age taken by the Osages five or six years ago. 'The restoration of these captive girls to their respective nations will, it is expected, facilitate the intercourse aimed for, conciliate the Indians and pave the way to desirable treaties.

June 29. Camp Cass. The command marched at nine o'clock westwardly fifteen miles. Capt. Brown, Company I, left in rear on account of breaking down of company wagon. Wagons great drazebacks to. military expeditions. Route today chiefly through timber, here and there some prairies; water scarce, beds of creeks dry. Encamped at the foot of a prairie mound four hundred feet in height, from the summit of which is seen a magnificent valley stretching in every direction some twenty-five or thirty miles. We found here good water and grazing.

June 23. Marched from Camp Cass at nine' o'clock, west by south seventeen miles; alternate prairies and timber; water less scarce than before, but warm, of a milky color and in pools. 
Iune 24. The advance was sounded at nine o'clock. Marched twentyone miles west by soutl. Halted at four o'clock P. M. and encamped near good water and grazing; excellent spring impregnated with sulphur and iron. Capt. Brown's company found us this morning. Road today chiefly through timber. Met two infantry soldiers going from the post at the mouth of Little River to Fort Gibson.

June 25. Col. Dorge and staff reached Camp Canadian on the west bank of the Canadian thirteen miles from last camp at twelve oiclock; reported to Gen. I.eavenworth, whom we found in cimp. Command came up at two o'clock. Road today through open, level prairie, well 'watered. Crossed the Canadian half a mile below the mouth of I.ittle River. Canadian two hundred yards wide, bed nearly dry, low banks. Indian name signified "River without banks." Near the east side passed Lt. Holmes' Seventh Infantry, with the company of the Seventh Regiment Inft. Lt. Holmes just commenced to build a fort and quarters for two companies at Camp Canadian. Another sulphur spring and good grazing and water.

.June 26. At half past eight o'clock Col. Dodge, a part of his staff, a detachment of twenty Dragoons and our bands of Indians preceded the command and found Gen. Leavenworth at Camp Osage, five miles south of Cave Creek; halted at half past five oclock P. M. thirty-two miles from Camp Canadian. Streams today frequent and abundantly supplied. The regiment, under command of Lt. Col. Kearney, left camp at half past eight o'clock; left twenty-seven sick men at Camp Canadian with Asst. Surgeon Hailes and Lt. Edwards in charge. Lt. Cooke was left here sick. T'en miles from Camp Canadian passed a band of Osages, between five and six hundred in number, employed in curing buffalo meat. Second chief of the Nation (Black Dog) in command, famous as a warrior. Two Osages joined us as volunteers.

June 2\%. Left Camp Osage (Gen. Leavenworth in company) at half past six o'clock; marched twenty-three miles westwardly, and encamped on a creek at the end of a thirteen mile prairie; limestone, excellent streams of water, and frequent. Soil in general, since leaving Fort Gibson, light and sandy, but often rich and well adapted to grain. Crossed Blue River ten miles from Camp Osage; saw in the vicinity much rich iron ore scattered over the surface of the earth. Met with and killed the first buffalo seen since the commencement of the march. Mineralogy of the country thus far of secondary formation, sandstone, limestone, freestone and slate.

June 28. Set out at seven o'clock; marched westwardly twenty-five miles. Encamped on Bois d'Arc Creek. Passed a herd of buffale this morning, some thirty or forty in number. Indians with us killed six of them. Road today chiefly over brushy prairie and through timber, some open prairie; water plentiful and good; character of timber in general, small post oak and black jack. Some trees of Bois d'Arc, a wood valu- 
able to Indians for bows, a yellow elastic wood of great tenacity. Entered the Washita bottom eight miles on the day's route. Elm trees, sycamores and ash. Health of the party good.

Sunday, June 29. Camp Washita. Marched fifteen miles west by south, reached Capt. Dean's camp (two companies of Third Infantry) a a mile or two from the Washita, at half past twelve o'clock; encamped near him. Road today through timber and brushy prairie. Limestone gave place today to red sandstone; saw more iron ore. Delightful spring near Capt. Dean's camp. Capt. Dean informs us that Pawnees have been seen in the neighborhood within a few days.

June 30. Gen. Leavenworth declares his intention of commanding in person the expedition to the Pawnee country. Learned that some companics of infantry were to accompany us. lieuts. Northrop and Steen, with twenty Dragoons, joined us from west side of Washita; report Pawnees seen in that direction.

July 1. The regiment under Col. Kearney arrived at ten oclock $A$. M. and encamped near the Washita. Our detachment joined main Camp Washita; forty-five men and three officers sick. Licuts. McClure, Eastman and Ury. The surgeon attributes the sickness to exposure in the lieat of the day. Seventy-five horses and mules disabled. Rapid marching in the heat of the day and poor grazing at night are supposed to have been the causes. The "note of preparation" is now heard over the camp. All are engaged in making ready for a Pawnce chase.

July 2. Remained in camp.

July 3. Preparations for crossing the Washita, a platform upon two canoes fixed for that purpose. Whole day occupied with passage of the left wing. Horse and mule lost in crossing. Capt. Trenor joined. Osburne, a deserter from F Company, brought in by a party sent in pursuit of him. Sutler's wagon arrived. I.ts. Swords and $V$ an Derveer arrived. Great disappointment in not receiving by L.t. Swords, horse shoe nails. Sent blacksmiths to Fort Towson to make nails.

L.t. Edwards arrived with twenty-three men who were left sick at the Canadian on the 26th ult. Men chiefly recovered. Lt. Cooke had gone back to Fort Gibson on surgeon's certificate of ill health.

July 4. 'The right wing of the regiment crossed the Washita. Command encamped about four miles west from Camp Washita. Four horses drowned; last wagon passed over after dark in the evening. The Washita is a narrow stream about forty-five yards in width, water of a dark red color, banks bold; shores mirey; inconvenient landing for horses. Monsieur Bcyrick, botanist, \&c., joined us today with the view of accompanying the regiment to the prairie. Mr. Catlin, portrait painter, is also with us.

Gen. Leavenworth declares his intention of sending Col. Dodge with 250 men to the Pawnee villages. Gen. Leavenwortl changes his deter- 
mination to command in person. Left sick at Capt. Dean's camp near the Washita, Lts. Sword, McClure and Eastman. I.fft here - men for duty and 109 sick.

July 5. Change of camp promises to improve the health of the command. Fine range for our horses, who have suffered of late for want of good grazing. Our horses in general, tho' thin, are apparently well able, if treated with care, to perform the campaign before us. Spirits of the officers and men good. Sanguine expectations of a successful march upon the Pawnees.

July 6. Moved westwardly eight miles to Camp Leavenworth.

July $\%$. Marched at four o'clock P. M. westwardly five miles. Maj. Mason and a party of officers killed several buffalo. Gen. Leavenworth joined us a short time previous to setting out for Camp Leavenworth. Left him there. By his orders the regiment today was reorganized. Number of companies six, each consisting of forty-two rank and file. Left 109 men for duty and eighty-six sick. Left the following named officers : Capt. Trenor in command, Lts. Shambaugh (sick), Ury (sick), Bowman, Kingsbury and Van Derveer.

New arrangement of ofticers-Field Staff, Col. Dodge, Lt. Col. Kearney, Maj. Mason, Lt. and Adjutant Hamilton, Lt. Wheelock (temporarily attached).

Company B, Capt. Sumner and Lt. Burgwin

Company C, Capt. Duncan, Lt. Territt

Company D, Capt. Hunter, Lts. Moore and Steen

Company E, Capt. Perkins, Lt. Davis

Company H, Capt. Boone, Lts. Izard and Northrop

Company I, Capt. Brown, Lt. Edwards.

Companies $\mathrm{G}$ and $\mathrm{K}$ were temporarily broken up and divided amongst the six companies. 'The command, furnished with ten days' provisions, eighty rounds of cartridges per man, baggage reduced to lowest possible quantity, marched in two columns.

July 8. Waiting for lost horses. A stupid sentinel last night mistook a horse for a hostile Indian, fired and killed him, alarmed the camp and sent off in a stampede the rest of the horses. Recovered all save ten. The men of the regiment are excellent matrial, but unused to the woods. They every day discover deficiencies in this kind of service. Among the officers are several excellent woodsmen. Talent of this kind is exceedingly valuable to the regiment. We found here chalk.

July 9. The command marched at half past eight o'clock, northwest course, fourteen miles. Col. Dodge this morning received instructions from Gen. Leavenworth to send back a field officer to command at Camp Leavenworth. I.t. Col. Kearny was ordered to report to Gen. Leavenworth for that duty. Ten men whose horses were lost on the night of the 7 th inst. were sent back to Camp Leavenworth. Soon after 
starting this morning several persons on horseback were discovered, supposed to be Pawnees. Face of country by day, high and rolling prairie. Encamped in a small pritirie in sight of a large mound some three or four miles distant bearing south forty degrees west.

ruly 10. Cross 'limbers. Course today west sixteen miles. Country rough and broken, with but little water. Little rain last night and this morning. Cloudy weather during the day. Some buffalo killed during the day; not much water at camp.

fuly 11. Command divided into three columns, the right column under command of Maj. Mason, the center column under Capt. Hunter, the left column under command of Capt. Sumner. Country today small rolling prairies; bushy ravines; scrubby oak ridges, want of good water on the road; bad water at camp tonight. Several buffalo killed today. Course today west. Distance twenty miles.

July 1\%. Encamped in a grove of small open timber near a fine grove. Marched at eight o'clock. Course west, distance twelve miles. Slips of prairie, timber and bushy thickets. Camp Choctaw.

July 13. Passed through the last of the Cross Timbers and entered upon the Grand Prairie. Marched at half past eight o'clock from Camp Choctaw west by north twenty-three miles and encamped on a creek. Highly beautiful country tolerably well watered. Command impeded today by sick men in litters. Indians supposed to be Pawnees were seen today. Wild horses in large herds. One of the Indian guides caught one of them. Immense herds of buffalo. Passed several springs of rock oil (petroleum). Command halted at six $0^{\circ}$ clock P. M. Rear guard did not come up until ten, kept back by the sick falling to the rear.

July 14. Marched at half past eight o'clock, seventeen miles west; number of sick decreased. The command had advanced today about a half mile when on a hill to our right we discovered a party of horsemen. Our spy glasses soon determined them to be Indians. Col. Dodge halted the columns, ordered a white flag, and with it and his staff moved in the direction of the Indians. After some delay one of the party advanced upon full gallop, bearing a white flag on his lance. He proved to be a Spaniard, who, early in life, had been taken by the Comanches. Col. Dodge received him kindly, and through our interpreter, who spoke a little Spanish, made known to him our pacific disposition. Gradually the whole band, about thirty Indians, came to us and shook hands. They proved to be Comanches, discovered a good deal of alarm and eagerness to convince us of their disposition to be friendly. They rode good horses; were all armed with bows and arrows and lances, and carried shields of buffalo hide. We enquired where their village was; they answered "two days journey" and seemed anxious to conduct us thither. In reply to our inquiries concerning the Pawnees they seemed not to understand the term; told us the Toyash village was one day's 
journey from their camp; that they would send for the 'Toyash chief if we would accompany them to their camp. They signified, however, their desire to have Col. Dodge wait with his command in their camp, and go on the next day. Col. D. paid no regard to their requests, but showed an indifference to their movements and an independence of them which had the effect to make them follow us. 'They accompanied us; found another band, making in all some forty or fifty. 'They told us that they were a very numerous people. Col. Dodge answered that roe were a very numerous people, that more troops were coming behind with large guns. After we halted to encamp for the night they came to beg tobaceo and to talk, with Col. Dodge, who informed them that "the President, the great American captain, had sent him to shake hands with them; that he wished to establish peace between them and their red brethren around them, to send traders amongst them and remain forever friends." They shook hands with the Osages, Cherokees, Delawares \&c, who were with us, and seemed highly satisfied with their interview with us and offered to accompany us to the 'Toyash village. Country today bealutiful, open prairie, game scarce-two or three deer were killed-no buffalo seen. A herd of wild horses passed near us. Provision threatens to be scarce. Col. Dodge anxious to expedite business lest his men may suffer on this account. One or two horses broke down today.

'The Comanche is a fine looking Indian, in general naked. Some of them wore blankets. The squaws were dressed in deer skins, and are good looking women. Among them were several Spanish women, evidently long used to Comanche habits. Appearance of a Comanche fully equipped on horseback with his lance, bow and quiver, and shield by his side, is beautifully classic. This has been an interesting day to us; our goal seems in sight; uncertainty of reaching the Pawnee much lessened.

July 15. Marched at half past seven o'clock, twenty-four miles northwest. Some rain last night. The Comanches left us this morning with the exception of one, who remained as guide. He assures us that we shall reach the Comanche camp tomorrow. Col. Dodge learned that the Kiowas, Comanches, and the hand called by us the "Pawnee Picks" but correctly termed the Toyash, are friends and to a certain degree allies and mingled so as to be, except in language, much the same people. The Comanches are, so we learn, the largest band, the proudest and boldest. Them, therefore, the Colonel has resolved to visit first; thence to the Toyash village, establish friendly understandings with one or both, or war with one or both, as may be. Officers and men on the alert as if in the atmosphere of war.

$J u l y$ 16. Marched at nine o'clock, halted at half past two oclock; course north by west, distance twelve miles. An accident occurred in camp last night. Sergt. Cross was shot by a dragoon, through the hip. 
We had marched three or four miles when we discovered a party of Comanches on our left. Col. Dodge sent two officers to meet them and shake hands with them. They were a hunting party some ten or twelve in number. We brought them to Col. Dodge. The columns were halted; they shook hands with the Colonel and his officers and the Indians. We then moved on together for the Comanche camp. The Pawnee girl recognized an old acquaintance in the captain of this party and rendered service by interpreting what he said, through the Osages. The Comanche captain informs us that it is but a short distance to their camp. His people wish to be our friends, \&c. 'Two or three miles with our new friends brought us in sight of their camp, situated in a valley. Here we met about a hundred mounted Comanches who had come out to weicome us, and evidently not a little alarmed. We shook hands with them, the Cherokees, Osages, \&c., advanced and performed the same ceremony, when we all moved together for their camp. On arriving near it they invited us to cross the creek and encamp with them. Col. Dodge, however, preferred having the creek between us and our red friends. This day has been a very interesting one, absolutely so, especially so, as we were anxious, impatient, and uncertain as to the movements of the Indians. Six nations, some of whom had but recently been at war with each other, shake hands together-a form, 'tis true, but a type, we helieve, of a permanent peace that must promote the interest of all. Our Camp Comanche, an admirable position, the steep bank of a creek in front and a ravine bounding the other three sides; habitual form of our camp, a rectangle; horses picketed within it at night, and surrounded by a chain of sentinels; orders issued that no man should visit the Comanches, nor officer, without special permission. The Comanches have hoisted an American fag over their camp, which contains more than two hundred skin lodges, lierds of horses, in all not less than 3000 , are grazing around them. They have been here, evidently, but a day or two. 'Their chief is absent with a hunting party. We are now in sight of a chain of peaks, so called, mountains bearing south and west. Behind these are the T'oyash villages. Some of these mountains cannot be less than 2000 fect above the prairie at their base.

Number of sick, twenty-nine; in litters, four. Our guide yesterday was not a little wavering in his disposition to serve us. Col. Dodge presented him with a gun, which produced a fine effect upon his spirits. He could not hear the Pawnee girl, but no sooner was he in actual possession of the Yanger and felt the well filled cartridge box buckled around his body than his grave face became wreathed in smiles, his sense of hearing was suddenly restored, his arms sawed the air with signs, and through the magical influence of the gun we gained several fragments of useful information. We are exceedingly unfortunate in not having an interpreter. Our Spanish interpreter, a Cherokee, is very imperfect.

July $1 \%$ Comanche chief still absent. Some of our oflicers pur- 
chased wild horses today. A blanket or butcher knife is equivalent to a horse. Waiting today for the Comanche chief to return to his camp. Col. D. hepes to be able to induce him to accompany us to the Toyash villages. The Kiowa girl is quite sick today. One of the Comanches informs us that their great chief will be here tomorrow when the sun is high, and that he can talk to the Kiowa and Pawnee girls.

July 18. The chief has not arrived; doubt somewhat the sincerity of the Spaniard who informed us he would certainly come. The Comanches visit our camp and trade with us. Monsieur Beyrick, the botanist, left us on the seventh instant. Number of sick today, thirty-three; three officers sick. Waited for the chief until ten o'clock, when the advance was sounded; marched seven miles westwardly, found a Pawnee Mahaw who has been to the Toyash village and who promises to guide us thither. 'Two miles from camp the command delayed two hours waiting for the litters to come up, six litters including Mr. Catlin's. Remarkable absence, day and night, of flies and mosquitoes. A chain of hills five miles from us bearing south by west. Country exceedingly beautiful; soil good; water abundant; grazing excellent. 'The season is a remarkably dry one, but we have suffered very little for want of good water. Our men seem somewhat discontented on account of scarcity of game. They are very improvident; brought ten days' provisions on the 7th, with orders to make it last twenty days; have been supplied with plenty of buffalo meat till within a day or two, yet many of them are entirely without provisions. Plenty of deer in the neighborhood, but no buffalo-out of the buffalo range today. Our sick encumbered so much that Col. Dodge resolves to leave them behind.

July 19. Marched at eight o'clock for the Toyash villages. Command reduced to one hundred eighty-three men; left in sick camp, covered by a breastwork of felled timber, seventy-five men, thirty-nine of these sick. Lt. Moore left here sick. Surgeon Findley for duty; Lt. Izard in command; left our jaded horses. Marched twenty-three miles southwest. 'Two miles from camp began to ascend hills, apparently a ridge of mountains running south by east. Curious regularity of the limestone upon the first hills passed over, rows of pavement resembling at a little distance furrows in a field. Road rough, leading over rocky ravines and close passes in the mountains. Our guide seems to have chosen the most uneven and circuitous route; height of these mountains from 200 to 1500 feet. Wagons nor artillery could possibly pass these hills. Halted at three o'clock and encamped near a creek. A few miles before reaching our halting place for the night the character of the country changed. Secondary formation gave place entirely to primitive rock. Mountains of granite, almost wholly without soil. Upon the side of one of them noticed a shining spot, apparently a waterfall, glistening in the sunlight. An old woodsman astonished us by informing us that it was a mass of salt. No buffalo. Our unshod horses 
suffered very much today. Wild horses in abundance, and bears. Many deer were seen, a few were killed. Scanty allowance of provisions for our men. We march too fast to be able to hunt much on the road. Game is now divided among the command with great care. Marched in three columns; baggage reduced to three pack horses to each company.

July 20 . The command moved at half past seven o'clock, west course. Halted at half past four o'clock, thirty-seven miles. Road literally of granite rock for miles. After a few miles struck high prairies thinly scattered with bushes, then ravines and difficult passes; immense blocks of granite piled on each other from 500 to 1000 feet in height. Many horses gave out today. Traces of buffalo, but saw none. About the middle of the day's march the mountains became more detached. Passed today what is called $\mathbf{a} \cdot \operatorname{dog}$ village. The prairie dog, or marmot, is an animal somewhat larger than a squirrel, with a head like a dog. They live in holes in the ground about twenty paces apart from each other; five or six miles were covered by the habitations of these little animals. We encamped five miles from the Toyash village, which is situated on a branch of Red River. Soon after we had pitched our camp Lt. Northrop was directed to pursue and endeavor to bring to camp an Indian who was discovered on horseback. Lt. Northrop, after some difficulty, induced the Indian, who proved to be of the Toyash nation, to accompany him. He was very much alarmed, conversed readily with the Pawnee girl. We behaved kindly to this Indian, assured him of our friendly disposition, and allowed him to return to his village. The 'Toyash girl is now of very great service as an interpreter. The 'Ioyash band not coming out to meet us today convinced us that they had either fled or had determined to make a stand and give us a fight. Bayonets were fixed and every preparation made for a conflict. Water today at our camp, salt. Width of the branch of Red River about 500 feet from bank to bank. Water low. Dutch, the Cherokee guide, very ill; the Kiowa girl ill also.

July 21 . The command marched at eight o'clock for the Toyash village. Proceeded a mile or two, when we met about sixty Indians who had come out to meet us. Shook hands with them and moved on in company with each other. They stated that the principal chief was absent on a visit to the Pawnee Mohaw country; passed their cornfields on our way to their town. These cornfields are well cultivated, neatly enclosed and very extensive, reaching in some instances, several miles. We saw also, here, melons of different kinds, squashes, \&cc. The Indians discovered a, good deal of alarm as we approached their village, frequently halted, and begged Col. Dodge not to fire upon them. Col. Dodge promised them safety. These Indians are chiefly naked and are armed with bows and arrows. They have few horses, and seem altogether an unwarlike people. Before we started this morning the uncle 
of the Pawnee girl rode up to our camp. He embraced his relation and shed tears of joy on meeting her. We soon reached the village, which is situated immediately under mountains of granite some six hundred feet in height. In front of the village runs the river. We counted near 200 grass lodges. These are made of poles fixed firmly in the earth, fastened together at the top, and thatched substantially with prairie grass and stalks from their cornfields. Many of the lodges are thirty feet high and forty feet in diameter. In the center of the floor a shallow excavation serves as a fireplace. Around the sides are comfortable berths large enough to accommodate two persons each. We encamped on a fine pasition about one mile from the village. 'Toyash men are less fine looking than the Comanches. Their women are prettier than the Comanche squatws; indeed, some of their girls are very pretty, naked save a broad garment of dressed deer skin or red cloth worn about the middle. Some of the men wear coats of red cloth obtained from the Spaniards of Mexico. Most of our officers visited them on the day of our arrival and were hospitably entertained. Our own provisions were almost entirely exhausted. We had met with little or no game for several days, and found most excellent fare in the dishes of corn and beans, which they dress with buffalo fat. They served us thus liberally, and for dessert gave us watermelons and wild plums. Our men purchased green corn, dried horse meat, and buffalo meat. We depended, during our stay with them, upon their dried meat and corn, which with vermilion and articles of clothing, knives, \&c., we were able to purchase of them. The Comanches now began to arrive.

July 22. At the Toyash village Col. Dodge and his officers met, agreeably to previous notice, the 'loyash chicfs and natives in council. Council being in order, Col. Dodge proceeded to speak as follows: "We are the first American officers who have ever come to see the Pawnees. We meet you as friends, not as enemies, to make peace with you, to shake hands with you. The great American Captain is at peace with all the white men in the world. He wishes to be at peace with all the red men in the world. We have been sent here to view this country and to invite you to go to Washington, where the great American chief lives; to nake a treaty with him, that you may learn low he wisles and send among you traders, who will bring you guns, blankets and everything that you want. The great American Chief wishes also to make peace between you and the Osages-you have been at war with the Osagesand to secure peace between you and the Cherokees, Senecas, Delawares, and Choctaws and all other red men; that you may all meet together as friends and not shed each other's blood, as you have done. On our way to your village we met a party of Comanches. "We showed to them a white flag, which said to them 'we wish to be friends.' 'I'heir principal men were gone to hunt. We treated their old men, women and children with kindness. We gave them presents. They had many horses. We could have taken their horses from then, but did not. We 
showed to them that we wanted to be at peace with them. They told us that you were their friends; we were glad to hear it. We have come to your town and have found you as defenseless as the comanches. We have treated you as we treated them. The American people show their kindness by actions, not by words alone. We have been told that a white man was taken prisoner by you last summer, that a boy was made prisoner by you last spring. We have come now to require the boy at your hands, for we are told he is in your town. Give us the white boy and we will give to you the Pawnee girl that we have brought with us. We wish all that has passed to be put behind us, to be forgotten. We wish to shake hands with you and be friends. You must now give me a positive and direct answer in regard to the white man who was made prisoner last summer and the boy who was taken last spring." The chief, We ter ra shah ro, replied "I know nothing of the man whom you say was taken last summer; the white boy is here."

Col. Dodge resumed, "I wish the boy brought to me. I will then give to you the Pawnee girl. This act, together with all the information that you can give concerning the man who was seized last summer, will be the best proof that you can give of the sincerity of your disposition to shake hands and be at peace with us. I cannot leave the country until we obtain possession of the boy and gain information respecting the man who was taken last summer. His name was Abby. He was taken between the Blue River and the Washita about this time last year."

Chief: "I know nothing of it. I believe they were Camanches who took the man." On receiving some intelligence from one of his friends, the chief continued, "I remember now the Oways who live south did it."

Col. Dodge: "Do the Oways hunt on the grounds between the Blue and Washita rivers?"

Chief: "They hunt there, and I have heard that they took the man 'Abby' and when they got near their camp they killed him."

Col. Dodge: "How far do the Oways live from here?"

Chief: "l'hey follow the buffalo as the Comanches do, they have no town."

Here a pistol was accidentally fired in the Council lodge, which caused much confusion. It was soon explained, however, and business proceeded. The white boy, who had been sent for, was brought in and presented to Col. Dodge. 'The boy was entirely naked, about seven years of age. His name is Matthew Wright Martin.

Chief: "I am glad to shake hands with you, with the red men that you have brought with you, the Osages, Delawares and Cherokees. The principal chief is not here, but you are as gladly received as he would have welcomed you. The chief has gone to the country of the Pawnee Mahaws; he believed that you had gone that way. The father of the 'loyash girl went with the chief to seek his daughter."

Col. Dodge: "How did the Comanches obtain the American Flag I saw flying in their camp?" 
Chief: "The Pawnees from La Platte sent two flags, one to the Waycoahs and the other to the Comanches."

Col. Dodge: "Do the Spaniards come here to trade with you?"

Chief: "They do; they left us not long ago and went west."

Col. Dodge: "The Americans will give you better and cheaper goods than the Spaniards do. Tell me if you know where the ranger, Abby, was taken, and how he was killed."

Chief: "I have inquired and have learned this day that the Indians who live near St. Antoine in Mexico captured Abby and that they killed him on Red River.

Col. Dodge: "What Indians kill [sic] our Santa Fe today?"

Chief: "There is a roving tribe of very bad Indians called Wakinas; they range north of the country of the Arkansas."

Col. Dodge here presented the girl to her friends, whereupon they conducted her from the Council.

Col. Dodge: "I am very much pleased at the exchange of prisoners. I hope the friends of the girl will be happy with her. She is a good girl. I wish her well. I will restore the little boy to his mother; her heart will be glad, and she will think better of the Pawnees. A bright sun has shined on us today. I hope the Great Spirit will let it shine continually upon us. You have some Osage prisoners. The Osages have Pawnee prisoners. We will exchange and give you your Pawnee friends, and you shall restore the Osages to their friends. How many Osages have you?"

Chief: "There are Osages here; they are men who were raised here and do not wish to leave us. The Delaware woman and boy that we took died of the smallpox. A great many Toyash have died of the smallpox."

Col. Dodge: "The American President will have a treaty of peace made between you all, then you will meet and exchange prisoners. 'This will be done when the next grass grows. 'The Osages who are with the Pawnees who then wish to return to the Osages will be able to return, and the Pawnees who are with the Osages can come back to their people."

Chief: "We wish to have it done soon."

Col. Dodge: "The American President wishes to see some of each nation shake hands before him. He will give presents to those who visit him, and $\mathrm{fx}$ a permanent peace between their nations. Peace cannot be made with all the tribes till a large white paper be written and signed by the President and the hands of the chiefs. Will your chiefs go with me now to see the American President? I wish, also, to take with me some Comanche chiefs. T'he Presiclent will be happy to see you, and will make you, as I told you before, presents of handsome guns, coats, \&c."

Much demurring among the chiefs.

Col. Dodge: "Ihis is the proper time to make peace with the red 
men and the white men. If you do not seize this opportunity you may not have another; the bright chain of friendship can now be made bright between all the Indians and the white men."

Chief: "We do not like to pass through the timber; it will be hard for our horses to pass through the thick timber country between us and the white men."

Col. Dodge: "There are roads. A big road is now being made."

Chief: "We have met here as friends; we hope to remain so. The Great Spirit has seen us as we see now the white men, Cherokees, Osages, Delawares, and Senecas, as friends. We hope to remain so."

Col. Dodge: "I hope so. How came you by the Negro boy who is here with you?"

Chief: "This Comanche brought him. He found him on the Red River. You can take him and do as you please with him."

The Council here closed.

July 23. Wa ter ra shah ro and two other principal men met Col. Dodge this morning at his tent and held further talk with him. The four leaders of the bands of Indians with us were present at the talk and participated therein.

Col. Dodge spoke as follows: "Toyash Chiefs: I told you yesterday that I wish to show you the road that leads to the great American Captain and make you acquainted with the Indians that live on the way thither. Have you thought of going with me? Our Great Father wishes you to see the red men who live on the way, that you may be the better able to settle all difficulties with them. You shall be well treated, presents shall be made to you, and you shall be sent back in safety. Peace cannot be made unless some of you go. I am not the Great Captain, I am ordered by him. He only can make peace with you and other red men. I wish only a few of you to go with me; I wish you to go willingly and as friends. Had I chosen to force you to go it would have been easy for me to do so. You see I do not wish to force you." After a good deal of consultation one of the chiefs (a Wacoah) consented to go. Here the following interesting ceremony took place:

The boy whom we recovered yesterday is the son of the late Judge Martin of Arkansas, who was killed by a party of Indians some weeks since. The son was with his father on a hunting excursion, and became parted with him (his death however, he did not witness, and is now in ignorance of it). The boy relates that after being parted from his father the Indians who had taken him were disposed, save one, to kill him. This one shielded him and took care of him in sickness. Col. Dodge, as a reward for this noble kindness, gave him a rifle, and at the same time caused the little boy to present him with his own hand, a pistol. Col. Dodge now assured the chiefs that they should receive further presents if they would go with him to his country; that he regretted he had nothing of value with him, but begged them to accept some rifles and pistols, which they did with much evident satisfaction. 
We ser ra shah ro and the other chief men with him here consulted some time together on the subject of visiting the President. We ser ra shah ro spoke. "We have been at war with the nations which we see around us today; we wish now to make peace with them."

Col. Dodge answered him: "It is the wish of the President that you make peace with them; that you present to each other clean lands. It is to effect this that I wish you to go with me."

The Chief resumed: "We wish much to make peace with the Osages. We have been long at war; we wish to see the lands of the Creeks and Cherokees also, to shake hands with all. We want now to hear those Indians who came with you speak to us."

"The chief men of the four parties now spoke as follows: Dutch, the Cherokee: "I am now going to tell you what the chief of the Cherokees bade me to say to you if we met as friends. He says to you his people wish to come to you without fear, and that you should visit them without fear. $\mathrm{My}$ heart is glad that we are all willing to be friends. $\Lambda$ long time ago it was so; there was no war between us. I am rejoiced and my people will be rejoiced, when they hear that it may be so agatin. Look at me, you see I speak truth. I have no more to say."

Beatte, leader of the Osage band: "We came for peace. I lave brought a few Osages who were not af raid to come among you with hearts inclined for peace. We look on our frriend (Col. Dodge) as our father; he is a true father to us all. I lope you will believe all that he says to you, and trust he will prove a father to you. We wish you to visit our people, to see how we live since the white men have been our friends. They have made us happy; they will make you happy. You should go with our father as he wishes. You must then come and see the Osages. I have said all that I can say."

Mon pi sha, an Osage youth, spoke to the Toyash men: "We shake hands with pleasure. I am nothing but a boy. My fatler was an Osage chief. We wish to be your brothers. Boys fight. We wish to be peaceable men and friends. Our good father here has made, in coming to you, a great road. We hope it will never be stained with blood. My father told me he was once a wild Indian; that white men taught him to be happy, instructed him how to build houses, to raise cattle, and live like white men. I was sent to the white man's school (missionary school), was taught to read and write. 'This will be extended to you if you make peace with white men. Your buffalo will be gone in a few years. Your Great Father, the President, will give you cattle and teach you how to live without buffalo."

Geurge Buttet (Pon da gue sa) spoke: "When I tell the Delawares that we are friends and can hunt now without warring together, then they will be happy. Our children will hereafter be happy and not fear each other. We will no more fear the prairie Indian, and you will not be afraid of us."

Col. Dodge resumed: "I am glad to hear what our firiends say to 
you. I must say to you now that I am very sorry that a few of our horses got into your corn fields last night. I shall pay you for the damage done. It is not my wish to disturb your property in any manner. White men will always he just to you. I must repeat, too, that I regretted that the pistol was accidentally fired in the council lodge yesterday. I did not wish to alarm your people. I was pleased with the coolness of your chief : he was not alarmed. I now wish you to consider if some of you will go with me."

The chief signified that they would go home and decide who should accompany the command on its march back, and accordingly left our camp. Many Comanches arrived today, amongst them the principal chief, 'la we que nalh and two other chiefs.

Col. Dodge held the following talk with them in his tent: "I'he great Anerican Captain lats sent me to view this country and to offer the hand of friendship to all the red men who are here. He wishes to see you all at peace with each other; he desires you to come and see him, that he may fix a permanent peace with your tribes. He will make you presents and he will send some traders among you who will serve you with a great many things that you want to make you happy. 'The President, who is a good father to you, wishes to see you at peace with the Osagres, Cherokecs, Delawares and all red men. We have endeavored to give you evidence of our friendship; we did so when we passed your camp. You were not there. Your women and children were defenseless; we treated them kindly; we confided in you too. Our sick men we left behind near your camp."

Ta we que nah replied: "I pissed a night in your camp with your sick men. They treated us with kindness."

Col. Dodge: "You say the Indians over the Red River are your enemics; they kill you when you meet. These are Mexican Indians and do not make treaties with our great father, the President, but he will protect you when you make peace with the Osages and other tribes that have been at war against you. 'The flag that you have came to you from the Great Father at Washington. The Pawnee Mahaws have such a flag, and all other red men who are our friends. Whenever you show it you will be known as friends. I was glad to see the flag over your camp."

The chief spoke: "I wish to be at peace with you. 'There are many bands of Comanches. I shall visit them all this year, and will say to them what you have said to me. They will all be glad to make peace with you. I am an old man now, but never since I was a boy did I kill one of your people. You ask me who killed the ringer, Abby. I can tell you, for I remember when this white man was taken. The Texas Comanches took this white man and carried him over the Red River and killed him there.

Col. Dodge: "I wish some of you to go with me, that you may see our country and that peace may be fixed strongly between you and the 
red men, as well as between ourselves. The Pawnee Mahaws met the Osages and Delawares and Cherokees on our lands, and there made peace. They were enemies before; they are now friends, and do not hate each other. We wish you to come to us and make, in the same way, peace with us."

Ta we que nah: "You have a girl who was taken from our friends, the Kiowas. I have a Spanish girl. I will give you the Spanish girl in exchange for the Kiowa girl that you have brought with you."

Col. Dodge: "I wish to secure your friendship and the friendship of the Kiowas. I wish you to accompany me. I wish some of the Kiowas to go also, but I do not mean to sell the girl to them. I mean to give her to her relations and friends without price. I will give the girl to her tribe. They shall see how much their friends we are."

Ta we que nah: "If I go with you I shall be afraid to come back through the timber."

Col. Dodge: "I pledge myself that you shall be safely conducted back."

'Ta we que nah: "I cannot go myself; my brother will go with you."

Here the talk was interrupted by a band of some twenty or thirty Kiowas rushing on horseback into camp and almost into the door of Col. Dodge's tent. The squaws and children fled in great alarm. The indignation of these Indians against the Osages had been kindled to a great pitch and could scarcely be kept in respectful bounds in their relation to us. 'The Osages not many months previously, murdered a large number of the women and children of the Kiowas whilst the men were absent hunting. We held in possession, of which they were informed, a Kiowa girl who was taken on the occasion of the massacre alluded to. The Kiowas having just arrived, were not aware of the intention on our part to restore the girl, and consequently presented themselves in a warlike shape that caused many a man in camp to stand by his arms. Col. Dodge, however, immediately addressed them with assurances of our friendly disposition, and gradually led them into gentleness. They are a bold, warlike looking Indian. Some of their horses are very fine. They ride well, and were admirably equipped today for fight or flight; their bows strung and quivers filled of arrows. They kept their saddles chiefly. A relation of the Kiowa girl embraced her and shed tears of joy at the intimation that she should be restored to her father and friends. She proved to be a relation of one of the chiefs. An arrangement was now made for a general council to be held the next day between the Comanche, Toyash and Kiowa nations.

July 24. At ten o'clock the chiefs of the Council began to assemble at the place appointed for their meeting, which was in a wood about 200 yards from our camp. The father of the Kiowa girl, having learned that she was to be restored, in a speech addressed to the Kiowas, whose numbers every moment increased, gave vent to his joy and praise of his white friends. All came mounted and armed. Many of our officers 
were present. There were not less than 2000 mounted and armed Indians around the Council. Great excitement prevailed among the Indians, but especially with the Kiowas, who embraced Col. Dodge and shed tears of gratitude for the restoration of their relative. An uncle of Wa ha sep ah, a man of about forty years of age, was touchingly eager in his demonstrations, frequently throwing his arms around Col. Dodge and weeping over his shoulders; then invoking blessings upon him in a manner the most graceful and ardent. The women came in succession and embraced the girl, who was seated among the chiefs. 'The Council being now in order and the pipes having made their rounds, Col. Dodge addressed the Comanche chief, who sat on his right, and who interpreted his words to the Kiowas, whilst a Toyash Indian who spoke the Caddo tongue communicated with the 'Toyash men from Chism, one of our Cherokee friends who speaks English and Caddo.

"I am glad to see together the great chief of the Comanche nation, the chiefs of the Kiowa and Toyash people, and the American officers who are with me. We have been strangers until now. I am glad to mect the captain of the Comanches ('lar me que ne). You must be a great man and have much power with all the tribes around you. I ask you to urge to these Indians what I have said to you, that we are your friends, and that to secure our mutual and lasting friendship it is better for some of each of you to go with me as I have before mentioned to you."

Here another band of Kiowas, about sixty in number, rode up, led by a principal man handsomely dressed. He wore a Spanish red cloth mantle, prodigious feathers, and leggings that followed his heels like an ancient train. Another of the chiefs of the new band was very showily dressed. He wore a perfectly white dressed deer skin hunting shirt trimmed profusely with fringe of the same material and beautifully bound with blue beads, over which was thrown a cloth mantle of blue and crimson, with leggings and moccasins entirely of beads. Our new friends shook hands all around and seated themselves with dignity and grace that would well have become senators of a more civilized conclave.

Col. Dodge resumed: "Kiowa chiefs, I herewith present to you your relation; receive her as the best evidence of the sincere frindship of Americans. Our great captain, the President of the United States, purchased this girl from the Osages, who took her from your people, and has sent me to restore her to the arms of her friends who love her.

"The Comanche chief, Ta me que nah, offered me yesterday in exchange for her a Spanish girl. I would not accept of his offer, for the delivery of the girl is an act of justice, and is but one of many acts of kindness that the great American Captain will be glad to show to you.

"You and the Indians who came with us have long been at war with each other; it is time you were at peace together. It is the wish of the President to secure a permanent good understanding among you all. He will send traders among you. You want guns, blankets, \&c. The 
buffalo are becoming scarce; they are less and less every year. You shall have cattle which you can keep with you. You can plant corn and cultivate the soil as the Cherokees and other Indians do. Here is a young man, Mr. Chadrick, who has come out with me to see you, and who will return next summer and bring goods and trade with you. I now wish you to consider the invitation given you to go with me, and assure you you shall receive presents and be safely conducted through the timber country."

One of the chiefs inquired "Will you go tomorrow?"

Col. Dodge: "I wish to go as soon as practicable, as we have far to go. I wish you to visit Gen. Leavenworth, another of your friends, and a captain under the Great Captain. He wishes to see you. He has never seen you. I should be glad to introduce you to him, two chiefs from each nation or one chief and some of the warriors of each people."

Titche totche cha, chief of the Kiowa, signified his willingness to go. We ta ra shah ro, an old chief (seventy years of age) urged his red brethren to rely on the truth of Col. Dodge's words. "He is a good man," said he, "believe his words."

The father of the Kiowa captive begged Col. Dodge to accept of a present, which the Colonel declined, repeating what he had siid before, that he did not wish for ransom or reward; that the child was given to the father as an evidence of the good feeling of his people for them.

Titche totche cha spoke: "The American Captain has spoken well today. The white men have shown themselves our friends. If a white man ever comes to my country he shall be kindly treated. If he wants a horse or anything that $I$ have he shall not pay for it. I will give him what he wants."

The Council here closed. We returned to our camp and left the Indians to decide in regard to accompanying us. It is on all accounts desirable to move from here. Our provisions prove unhealthy for our men, consisting entirely of green corn and dried horse and buffalo meat. The weather has been especially hot and dry. Our men, many of them sick, are without a physician or medicine. Two or three officers are, and have been for several days, ill of fevers. 'The Comanche squaws are very troublesome. They steal everything that they can secure. The Toyash women are infinitely more respectable. The difference in the character of these three tribes seems to be somewhat thus-The Comanche is an arrogant, jealous, savage Don. The Toyash a savage farmer, whilst the Kiowa is more chivalric, impulsive, and daring than either, reminds one of the bold clanning Highlander, whose very crimes are made by the poet captivating. This tribe has roamed more toward the Rocky Mountains till within a few years past.

July 25. The chiefs of three tribes early visited our camp. Col. Dodge presented them with guns and pistols. Fifteen Kiowas, including the chief, Titch totch ha, were the first mounted and equipped ready to march with us. The Comanche chief, very cautious and apparently 
suspicious, deferred till late, when four Comanches, a squaw, and our early acquaintance, the Spaniard, joined us. There was much delay on the part of the Toyash. At length, however, the old chief, We ser ra shah ro, a Waycoah, chief of a small band who speak the same language as the Toyash people and live near their town, and two Toyash warriors, rode into our camp and proposed to move with us.

The command, with the Indians, the white boy, and the Negro in company, marched at three o'clock, halted at five o'clock and encamped on a creek six miles east.

July 26. Marched at half past seven o'clock. Our guide, the Pawnee Mahaw, who had promised to remain with us, left us; he was no loss, for he had led us over a uselessly long route, over rocks and hills, through deep ravines, all of which our guide today, a Toyash, has avoided and in place thereof we have passed through a beautiful valley four or five miles in width, over an open, level prairie, leaving the granite roads on our right and left in the mountains. Course today, east; distance twenty-one miles; water scarce; grass very much destroyed by heat and dry weather. Encamped on a stream of good water, good grazing. Severe shower of rain, the first that has blessed us for many days. Parched corn and dried buffalo meat our fare. Health of command tolerably good. From conversation today with one of the Indians (Ski sa ro ka) an intelligent 'Toyash, we learn that their nation lived formerly south; that their oldest men were born there, and that they and the Comanches have long been in habits of friendly intercourse. They exchange buffalo meat for the agricultural products of the 'Toyash. 'The Comanches not much liked by the 'loyash; they cheat them and ride away. The Kiowas, a newer acquaintance, more lonest and gentle. 'The Conanches of 'lexas, a much more powerful tribe than those on this side of the Red River. They are called the Ho ishe Comanche.

July $2 \%$ Marched at half past seven o'clock; course east; distance twenty-three miles. Reached the sick camp at four o'clock. Found Lts. Izard and Moore both sick with fevers, also Mr. Catlin very ill. 'Twentynine sick men in both camps. Lt. Wheelock's servant left sick on the 19th inst., died in our absence. Our road today lay through a valley, occasional interruption from timbered creeks and small thickets, until we reached the Roaring River, a short stream, but contains a considerable volume of water, empties into the Red River. 'The Comanches who set out with us left us today on account, as they say, of the sickness of the squaw. The Spaniard, who seems to belong to that tribe more than to any other, remains with us. These Indians seem well contented and move without restraint, encamping with us at night, and setting out with the command or after it has marched, as they please. Col. Dodge and all the officers unable to account for not hearing from Gen. Leavenworth. From the short supplies taken we have reason to 
expect to hear from or meet with our wagons. Our buffalo meat very short and no game as yet.

July 28. Broke up the sick camp and marched at half past nine o'clock with the whole command, taking again with us the Senecas, who had bcen left to hunt for the men left at the camp. Excessive hot weather; forty-three sick, seven in litters. Course east by north, distance twelve miles. The heat today has been overpowering both to men and horses; water tolerable; course north from our trace going out. Camp tonight about six miles from former trace. Col. Dodge sent an express in search of Gen. Leavenworth to inform him of our return from the Pawnee villages. Col. Dodge resolved to wait in the buffalo range for orders from Gen. Leavenworth. Deer abundant today, one or two killed. One of the men killed a panther yesterday. Passed today many hills of gypsum.

July 29. Marched today at eight o'clock east by north; distance fifteen miles. Provisions very short. At twelve o'clock the cry of buffalo was heard, and never was the cheering sound of land better welcomed by wearied mariners than this by our hungry columns. The command was halted, and soon went together the report of Beatte's rifle and the fall of a fat cow. Halted at four o'clock. Killed two more buffaloes. Passed today more plaster of Paris. Road today over open rolling prairie between two forks of the Washita. Met a small party of Toyash Indians. Our red friends suffer exceedingly from the heat of the sun. We covered them this morning with shirts.

July 30. Marched at eight o'clock; weather excessively hot; course northeast fourteen miles. Course interrupted by frequent deep gullies totally impassible for wagons. Nine miles from camp passed the Washita. Good water today. Encamped on a fine stream; large fishes visible from the bank. Timbered creeks, black jack, elm and mulberry trees. More gypsum.

July 31. Marched at half past eight o'clock. Men in fine spirits. Abundance of buffalo meat. Course northeast, distance ten miles. Encamped on a branch of the Canadian. Three buffalo killed this morning. No news yet from express anxiously looked for. Face of country rolling prairie; frequent deep gullies. One of the Kiowas killed three buffalo with three arrows.

August 1. The signal for advance was sounded at half past eight o'clock. Course north by east, distance fifteen miles. Halted at half past one o'clock. Ten miles from camp crossed the Canadian. Plenty of water today. Passed the Canadian about one hundred miles from our ford going out. Abundance of buffalo, immense herds in every direction from the camp. Men employed at night in drying meat. Officers and men fortunate who have been provident enough to save a small quantity of corn for parching. Camp alarmed this evening by the cry 
of "Secure your horses from the buffalo." $\Lambda$ herd was rushing upon our camp, around which our horses had just been picketed, and had approached within two hundred yards of us, when our mounted sentinels changed their direction and thus saved us from another "stampedo". We have been fortunate in having had but one occurrence of this not uncommon evil with bodies of horses on the prairies.

August 2. Rest, welcome rest, for men and horses. Occupied in killing and drying buffalo meat for the anticipated march to Fort Leavenworth, probable distance thither four hundred miles. Our men not unfrequently lost in hunting; in several instances absent from camp all night. Our men find an excellent substitute for tea and coffee in a wild sage plant. We still have the advantage of being not at all troubled by flies or mosquitoes. The nights are so cool that the covering of a blanket is pleasant.

August 3. Moved a mile at half past ten o'clock for change of grazing and police. Our horses are in bad order, so much so that it is feared that they may not be equal to a march to Fort Leavenworth. May possibly be compelled to move to Fort Gibson to recruit and shoe them. Little Martin flourished and is a great favorite in the command. He is an uncommonly fine boy.

August 4. The command marched at half past eight o'clock; southerly direction eight miles along the Canadian in search of buffalo. They have fled from the vicinity of our last camp. Passed large herds of buffalo. The Kiowas dashed in amongst them and killed with their arrows a vast many of them. Grass very much dried; scarce affording subsistence for our horses. Col. Dodge had decided for marching to Fort Gibson. The prairie took fire today near our camp and was with difficulty extinguished.

August 5. Rested for the diy. Men employed in curing meat. The express to Gen. Leavenworth returned. Intelligence from Capt. Dean, Third Infantry, announces the death of Gen. Leavenworth. He died at his camp near Cross Timbers on the 21st of July. L.t. McClure of this regiment, died at the Washita on the 20th of July; bilious fevers. One hundred fifty men sick at the Washita.

August 6. Marched at eight o'clock for the fort at the mouth of Little River. Course southeast, distance twenty-three miles. Road through Cross Timbers. This is a timbered thicket; small black jack saplings so close as to require frequently the ax to make a road for a horseman. Five litters in our train; men in them extremely ill. Col. Dodge sent an express to Col. Kearney, who is at Camp Smith near the mouth of the Washita, directing him to move his command to Fort Gibson. Herds of buffalo broke and rebroke through our columns today. Encamped in timber in the bottom of a branch of Little River. Found excellent grazing in the pea vines. Litters came up several hours after the command. 
August 7. Our columns started at eight o'clock. Course south by cast. Gained eighteen miles. Still in the Cross 'Timbers, which promise to continue till we strike the road to Fort Gibson. A few small prairies interspersed amongst the severest black jack thickets. Our route today has been on the dividing ridge between the Canadian and Little Rivers. Scarcity of water; fortunately at the thicket found at four o'clock good water and grazing.

August 8. Marched at eight o'clock. Halted at three o'clock; distance eighteen miles; course east by south. Exceedingly warm day. Stubborn thickets. Crossed and encamped in the bottom of Little River; shallow stream, narrow bed, mirey shores. No water from morning till the halt for the night. Passed many crecks the beds of which were entirely dry. Our horses looked up and down their parched surfaces and the men gazed in vain at the willows ahead, which proved to mark only where water had been. The timber is larger here. Black walnut and sycamore, lime and freestones. The woods abound today in plums and a variety of finely flavored grapes. No longer any trace of the buffalo. Sick report numbers thirty men and three officers.

August 9. Marched at the usual hour and made twenty miles in a northeast course. Cross Timbers, but more open than for the last three days. Tolerable supplies of water. Soil sandy. Encamped at four o'clock in open timber near where we struck the road from Fort Gibson to the Washita, which was three miles from the post at the mouth of Little River.

August 10. Dragoon Camp Canadian. We drew from L.t. Holmes, commander of the infantry, Camp Canadian, at the mouth of Little River, provisions for four days. Lt. Holmes well advanced with his buildings, one block house and quarters for one company erected. Vast many sick. On our sick list, thirty.

August 11. Marched at eight o'clock. Left our sick whom we brought in litters, at the infantry camp. Gained on the road to Fort Gibson twenty-two miles. Our men happy with pork and flour.

August 12. Command moved at eight o'clock. Express returned from Camp Smith. L.t. Col. Kearney reports many sick; seventy-one for duty, forty-one sick; eight for duty at Camp Washita and seventy sick. Many of our horses disabled, led by men in rear of the columns. Tolerable water, wholly in pools. It is worthy of remark that the mules of the command look better than when we started on the campaign, while it would be difficult to select ten horses in good order. The command ordered to walk and ride one hour alternatcly; this relieves the horses.

August 13. Marched at half past seven o'clock and reached the Creek settlements at the North Fork of the Canadian, seventeen miles. The Toyash and Kiowas met the Creeks this evening and shook hands with them. We purchased here corn for our horses. Informed here by a 
citizen that the mother of little Martin had recently offered two thousand dollars for his recovery. She will soon be made happy by his restoration without ransom or reward.

August 14. We marched at eight o'clock twenty miles to our former Camp Rendezvous, from whence the regiment started on the 21st of June. Our horses are exceedingly worn, though somewhat aided today by the corn we gave them at the North Fork. The season is unfortunately late for grizing. It is only in timber that tolerable grass is found. Extraordinary heat today. The breeze comes against the face and hands with an unpleasant heat, so that one turns from it as from the keen blasts of winter. Water searce and in pools. Our men present a sorry figure, but one that looks Iike service. Many of them literally half naked. Sick list reduced to nineteen.

August 15. Marched at half past seven o'clock. Ar officer was sent in advance to purchase corn. 'The command marched fourteen miles and encamped three miles from the west bank of the Arkansas. Col. Dodge and staff, together with the Indians, crossed the river late in the evening, and reached Fort Gibson.

August 16. Fort Gibson. Major Mason and three companies ordered this side of the river. Capt. Sumner and three companies directed to remain in camp on the west side of the Arkansas.

August 24. Col. Kearney's command arrived yesterday. Great number of sick men and worn down horses. Officers belonging to it are Capt. Trenor, L.t. Swords (sick), L.t. Van Derveer (sick), Lt. Eastman (sick), Lts. Bowman, Ury and Kingsbury, Sergt. Halet (very sick). Runners have been sent to the chiefs of the Osages, Cherokees, Creeks, Chocktaws, \&ce, for the purpose of assembling them in council with the Indians who have accompanied us. Our friends from the prairie are in good health and are apparently contented. Little Martin is still with Col. Dodge, and the Negro we brought from the Toyash village has been delivered to his master.

\section{NAVIGATING THE CEDAR RIVER}

The steamer Black Hawk is doing a fine business on the Cedar between Vinton and the Rapids. She usually performs the downward trip in four and a half hours, distance sixty miles.-Dubuque Express and Herald, March 29, 1859. (In the Newspaper Division of the Historical, Memorial and Art Department of Iowa.) 
Copyright of Annals of Iowa is the property of State of Iowa, by \& through the State Historical Society of Iowa and its content may not be copied or emailed to multiple sites or posted to a listserv without the copyright holder's express written permission. However, users may print, download, or email articles for individual use. 